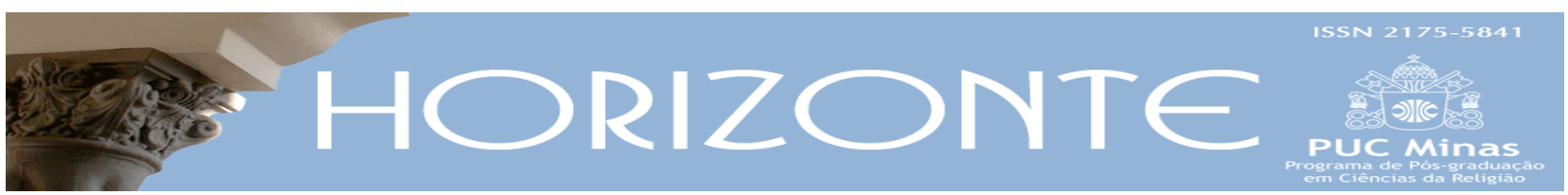

Temática Livre - Artigo original

๑용

DOI - 10.5752/P.2175-5841.2019v17n54p1623

\title{
De macumba a umbanda: \\ o processo de legitimação da religião dita genuinamente brasileira
}

\author{
From Macumba to Umbanda: \\ the legitimating process of a religion considered somehow authentic Brazilian
}

Mariana Ramos de Morais*

\begin{abstract}
Resumo
Este artigo aborda o processo de legitimação da umbanda, uma religião afro-brasileira, presente hoje em todo Brasil e mesmo no exterior. Diferentes intérpretes apontam que essa religião surgiu no Sudeste brasileiro nas primeiras décadas do século XX. As práticas nominadas "macumba" e associadas aos negros podem ser pensadas como a origem da umbanda. O estigma do feitiço, atrelado às práticas religiosas afro-brasileiras desde o Brasil colônia, também foi a ela transposto. No intuito de afirmá-la como religião, alguns grupos buscaram uma aproximação com o espiritismo kardecista, visando um certo "embranquecimento" de suas práticas e definindo-a como "genuinamente" brasileira. Outros grupos preferiram enaltecer sua herança africana. Este artigo focaliza, assim, as vias escolhidas por diferentes grupos, especialmente, na primeira metade do século $\mathrm{XX}$, para afirmar como religião práticas antes consideradas feitiço. Para tanto, apresento uma leitura crítica da literatura que aborda a conformação da umbanda, bem como seu processo de legitimação enquanto religião. Além disso, analiso textos produzidos pelos próprios umbandistas.
\end{abstract}

Palavras-chave: Umbanda. Macumba. Legitimação. Religião. Movimento federativo.

\begin{abstract}
This article aims to present the legitimating process of Umbanda as a religion. Umbanda is one of the Afro-Brazilian religions and, nowadays, it is present in all over the country and even in other countries. Different authors affirm that this religion appeared in the Southeast of Brazil in the beginning of the $20^{\text {th }}$ century. The religious practice called "Macumba" and associated to the Black people is thought as the Umbanda's origin. To affirm this practice as a religion some groups tried to associate it with Spiritism and to define it as an authentic Brazilian religion. Others preferred to exalt its African heritage. This article shows the different ways chosen by those groups, in the first half of the $20^{\text {th }}$ century. Therefore, it presents how the academic literature approaches the conformation of Umbanda and its legitimating process. Moreover, it analyses texts produced by the umbandistas themselves.
\end{abstract}

Keywords: Umbanda. Macumba. Legitimacy. Religion. Federative movement.

Artigo submetido em 5 agosto de 2018 e aprovado em 28 de outubro de 2019.

* Doutora em Ciências Sociais pela PUC Minas. Professora colaboradora da PUC Minas - PNPD/CAPES. Bolsista CAPES. País de origem: Brasil. E-mail: marianaramosdemorais@gmail.com 


\title{
Introdução
}

Em sua Música de feitiçaria no Brasil, Mário de Andrade sugeria, em nota, uma geografia religiosa em que "a feitiçaria nacional de origem africana ou de inspiração ameríndia” se distribuía da seguinte forma:

\author{
Macumba: Rio de Janeiro \\ Linha-de-mesa: Rio de Janeiro \\ Candomblé: Bahia \\ Candomblé ou Religião de Caboclo: Bahia \\ Xangô: Pernambuco, Paraíba \\ Catimbó: todo o Nordeste \\ Pagelança: Amazônia, e ainda norte do Piauí \\ Tambor-de-Mina e Tambor-de-Crioulo: Maranhão \\ Babassuê: Pará. (ANDRADE, 1983, p. 64).
}

O autor informava que essa era uma tentativa de distribuição geográfica da "feitiçaria" nacional, mas que ainda estava "bastante imperfeita" (ANDRADE, 1983, p. 64). Mesmo assim, apresentou-a no artigo Geografia Religiosa do Brasil, de 1941, uma referência para Roger Bastide (1995), que dedicava um capítulo de As religiões africanas no Brasil à geografia das religiões afro-brasileiras ${ }^{1}$. No citado capítulo de sua obra, Bastide descrevia as diferentes religiões afro-brasileiras ao mesmo tempo em que traçava comparações delas com o candomblé. Ele seguia, em parte, o proposto por Mário de Andrade, autor que consta no rol de suas fontes de pesquisa.

Assim, Bastide listou o predomínio indígena da Amazônia até Pernambuco, com a exceção do Maranhão, onde havia uma forte presença de africanos vindos do Daomé (hoje Benin), que fundaram o tambor de mina. O Maranhão seria uma região de transição para o catimbó, presente também no Piauí e nos estados fronteiriços. Já na Paraíba havia o Xangô, praticado ainda em Pernambuco, Alagoas e Sergipe. A Bahia era a terra do candomblé. No Brasil central, que na geografia bastidiana compreendia o atual Sudeste brasileiro - Minas Gerais, Rio de

\footnotetext{
${ }^{1}$ O artigo Geografia Religiosa do Brasil, publicado na revista Publicações Médicas (ANDRADE, 1941), foi extraído, em parte, da conferência Música de feitiçaria do Brasil (ANDRADE, 1983).
} 
Janeiro, São Paulo e Espírito Santo -, a macumba e o espiritismo de umbanda sobressaíam. Sendo que, em Minas Gerais, havia também o canjerê, cuja imprecisão das informações impossibilitava a Bastide afirmar se configurava uma religião ou não; e, no Espírito Santo, a cabula apresentava-se como uma prática de origem banta. O batuque era a religião dos negros do Rio Grande do Sul.

A relação apresentada por Mário de Andrade referia-se a uma realidade encontrada por ele no primeiro quartel do século XX. Bastide desenhou a sua geografia das religiões africanas em meados do mesmo século, já vislumbrando mudanças dentro da configuração que estava posta. Para ele, com as migrações internas, moradores de regiões mais "arcaicas" seriam levados a religiões mais "modernas", leia-se Nordeste, no primeiro caso, e, no segundo, Sudeste. A migração se refletiria também na mobilidade dos cultos. Em um ambiente hostil como o do Sudeste brasileiro, a umbanda seria a única forma possível de adaptação dos negros ao processo de urbanização e de industrialização (BASTIDE, 1995, p. 300-305).

A umbanda - para Bastide uma degeneração das práticas religiosas africanas mais puras - experimentou uma ascensão a partir da década de 1950, quando ganhou corpo o movimento federativo (BROWN, 1985; BIRMAN, 1985; NEGRÃO, 1996). Um dos principais objetivos das federações era atuar contra a repressão à prática da umbanda, empreendida pelo Estado por meio das forças policiais. Para garantir a defesa dos terreiros, as federações indicavam, com base em amparos legais, que eles deveriam ser registrados em cartórios. As federações se configuraram assim como mediadoras nesse processo, o que lhes rendeu o título de "sindicatos da umbanda", uma referência ao caráter assistencial que adquiriram, como demonstra Patrícia Birman (1985, p. 99).

Este artigo é sobre o processo de legitimação da umbanda. Trata-se de uma religião afro-brasileira, presente hoje em todo Brasil e mesmo no exterior, extrapolando os limites das geografias afro-religiosas acima descritas. Diferentes intérpretes apontam que essa religião surgiu nas primeiras décadas do século $\mathrm{XX}$ 
no Sudeste brasileiro. As práticas que eram nominadas "macumba" e associadas aos negros podem ser pensadas como a sua origem. O estigma do feitiço estava atrelado a essas práticas religiosas e foi transposto para a umbanda. Com vistas a afirmá-la como religião, alguns grupos buscaram uma aproximação com o espiritismo kardecista, visando um certo "embranquecimento" de suas práticas e definindo-a como "genuinamente" brasileira. Outros grupos preferiram enaltecer sua herança africana. Dessa forma, este artigo focaliza as vias escolhidas por diferentes grupos, principalmente, na primeira metade do século XX, para afirmar como religião práticas antes consideradas feitiço² ${ }^{2}$

\section{Narrativas de um surgimento}

Depois de correr a Minas barroca e se deixar encantar pelas danças dramáticas que cobriam o Brasil com uma alegria festiva, Mário de Andrade experimentava o que chamou de "feitiçarias". As suas "feitiçarias" não se restringiam ao candomblé baiano nem mesmo pregavam uma pureza africana, uma vez que eram afro-brasileiras, podendo ter influências indígenas. Nos anos 1930, ele organizou parte do que fora registrado em suas viagens na conferência Música de feitiçaria no Brasil. Dentre a variedade de "feitiçarias" que encontrou pelo país, nenhuma foi nomeada umbanda, termo que na época já era usado para designar uma religião presente no Sudeste brasileiro e que, no Rio de Janeiro, buscava se organizar burocraticamente com vistas a garantir o seu reconhecimento público. Talvez, estivesse ele se referindo à umbanda no trecho a seguir:

De S. Paulo pro Sul uma superstição mais avassaladoramente europeizada se aplica secamente às práticas do baixo espiritismo. Uma crendice mais céptica e infinitamente menos lírica, mais curiosa que amante ou tímida, já canta pouquíssimo, toda entregue ao susto das mesas trementes ou das agüinhas curadeiras. (ANDRADE, 1983, p. 23).

\footnotetext{
${ }^{2}$ Neste artigo, apresento uma leitura crítica da literatura que aborda a conformação da umbanda, bem como seu processo de legitimação enquanto religião. Além disso, analiso textos produzidos pelos próprios umbandistas. Para uma análise comparativa do processo de legitimação da umbanda com o do candomblé, ver Morais (2018).
} 
É o que se infere de alguns pontos dessa breve descrição da "feitiçaria" observada por Mário de Andrade nas regiões Sudeste e Sul do Brasil, tais como: a influência europeia; a mistura com o chamado "baixo espiritismo"; o fato de ser uma prática mais cética; a presença das "mesas trementes ou das agüinhas curadeiras". Neste último caso, há uma referência direta ao espiritismo kardecista, de origem europeia, e que foi uma das bases para a formação da umbanda. Diferentemente do candomblé, que ressaltava a sua herança africana, a umbanda buscará, em um primeiro momento, se afastar dela, muito embora se apoiasse em elementos das culturas negra e indígena, para se autodefinir como brasileira.

No referido texto de Mário de Andrade, a palavra umbanda era mencionada na reprodução do trecho de uma cantiga, o Ponto de Ogum3: Ôh êh Umbanda cangira-gira angulá. $\mathrm{O}$ autor não se ateve ao sentido que a frase ganhava para os partícipes do ritual. Ele estava voltado para o

formidável valor hipnótico que junge a música, desde o mais longínquo passado onde possa penetrar o nosso conhecimento, aos processos de invocação, propriação e exorcismo das forças sobrenaturais. A música, nas feitiçarias e atos mágicos, não é apenas empregada como processo de agradar a divindade: é usada como um elemento do homem entrar em contato com a divindade, exerce quase o papel do medium espiritista. E mais do que isso, é considerada como uma entidade generosa, litúrgica, que tem a função eucarística de pôr o indivíduo em êxtasis, comungando com deus. (ANDRADE, 1983, p. 44).

O Ponto de Ogum, que levara a uma descrição detalhada de Mário de Andrade, fora entoado em uma macumba, a "feitiçaria" que, conforme o poeta modernista, era dominante no Rio de Janeiro e seguia rituais especificamente africanos. No mesmo período em que ele tecia suas observações sobre as "feitiçarias afro-brasileiras", Arthur Ramos - que vinha da área médica assim como seu mestre, Nina Rodrigues, e, posteriormente, se engajou na construção da antropologia como campo disciplinar no Brasil - se voltava para a questão do negro, incluindo a sua religião. A macumba era definida por Arthur Ramos como

\footnotetext{
${ }^{3}$ No candomblé, Ogum é uma das divindades do panteão nagô. Mas também está presente nos louvores da umbanda, sendo caracterizado como um guerreiro, um soldado, vencedor de batalhas, como São Jorge.
} 
um ritual altamente sincretizado e formado a partir dos cultos africanos, ameríndios, católicos e espíritas, sendo praticada por negros de origem banta (RAMOS, 2001)4.

Ao relatar o seu fascínio pelo efeito e pelo lugar da música na macumba, Mário de Andrade evocava um universo simbólico que também era constituinte da umbanda. Umbanda, neste caso, não era a palavra contida no Ponto de Ogum, mas a religião que surgia entre as décadas de 1920 e de 1930, mesclando rituais de matriz africana às práticas do espiritismo kardecista, do catolicismo popular e de reinvenções das culturas indígenas.

Em seu As religiões africanas no Brasil, Roger Bastide (1995) - que, quando chegou ao Brasil, em 1938, manteve contato com Mário de Andrade distingue a macumba da umbanda, nomeada também por ele como espiritismo de umbanda5. Um dos interesses de Bastide na referida obra era entender o nascimento da umbanda à luz da sociologia. Assim, a macumba, para ele, referia-se às religiões africanas após a perda de seus valores tradicionais, no sentido de uma degeneração; a macumba seria uma expressão mágica da marginalidade do negro com o fim da escravidão. Ao passo que a umbanda seria a expressão ideológica da integração do negro à nascente sociedade de classes. As mudanças sociais, políticas e econômicas pelas quais passava o Brasil no primeiro quartel do século XX contribuíam, assim, para o surgimento de uma nova religião.

Diferentemente de Roger Bastide, embora adotasse também uma perspectiva integracionista, Cândido Procópio Ferreira de Camargo (1961) tomou o kardecismo como modelo para interpretar o surgimento da umbanda, entendida como uma maneira de adaptação dos migrantes, fossem do meio rural ou de pequenas cidades, à vida nos grandes centros urbanos. Sua pesquisa foi realizada

\footnotetext{
${ }^{4}$ Mário de Andrade tinha conhecimento da produção de Arthur Ramos, Nina Rodrigues, Silvio Romero, Manuel Querino, Câmara Cascudo, que são inclusive citados em Música de Feitiçaria no Brasil.

${ }^{5}$ Vale destacar que Roger Bastide passou a focalizar as religiões afro-brasileiras em seus estudos a partir da década de 1940.
} 
na São Paulo da virada dos anos 1950 para os 1960, sob a pujança do desenvolvimentismo industrial. A umbanda foi tratada por ele como um continuum do kardecismo.

Foi também a partir do kardecismo, porém no Rio de Janeiro, que Diana Brown (1985) apresentou a sua versão para o surgimento da umbanda que, para ela, remonta à década de 1920. Naquele período, ela relata, um grupo de kardecistas de classe média começou a incorporar tradições afro-brasileiras em suas práticas religiosas. Esta teria sido a forma encontrada pelo grupo para expressar os seus interesses de classe, suas ideias sociais e políticas, seus valores. Esse grupo estava vinculado a um médium chamado Zélio de Moraes, que, segundo narrativa de um dos mitos de origem da umbanda, havia recebido a missão da espiritualidade de fundar a nova religião ${ }^{6}$.

Na década de 1970, São Paulo e Rio de Janeiro foram cenários da pesquisa de Renato Ortiz (1978). As mudanças sociais também foram para Ortiz um caminho para se pensar a formação da umbanda, seguindo o viés de seu orientador, Roger Bastide, de quem emprestou o termo "embranquecimento" para subsidiar o seu argumento. Bastide afirmava, em As religiões africanas no Brasil, que o negro, para subir individualmente na estrutura social, necessitava aceitar os valores impostos pelo mundo branco, recusando aquilo que tem forte conotação negra, ou seja, precisava embranquecer-se. Nesse sentido, para Ortiz, primeiramente, houve um "embranquecimento" das práticas religiosas dos negros, seguido de um “empretecimento" de práticas espíritas e kardecistas. O “empretecimento" é definido por Ortiz como um movimento de uma camada social branca em direção às crenças tradicionais afro-brasileiras, que não resulta em uma valorização das tradições negras. O nascimento da umbanda é entendido por ele como fruto desses dois movimentos: o embranquecimento somado ao empretecimento (ORTIZ, 1978, p. 30).

\footnotetext{
${ }^{6}$ Para uma versão crítica sobre esse mito de origem, ver Giumbelli (2002).
} 
As interpretações apresentadas sobre o surgimento da umbanda a associam tanto à macumba - como aponta Bastide - ou às crenças tradicionais afrobrasileiras - como prefere Ortiz -, quanto ao kardecismo, vide Camargo e Diana Brown. São interpretações construídas no âmbito das ciências sociais e posteriores à conformação da religião, ou seja, são olhares externos, com um distanciamento temporal. Tais interpretações se baseiam, ainda que não mencionadas diretamente, nas articulações de praticantes das religiões afro-brasileiras - e aqui ressaltando a umbanda - no espaço público.

\section{Afastando o estigma}

Remontando ao início do século XX, as práticas religiosas dos negros eram, com frequência, enquadradas como crimes de curandeirismo, de magia, de feitiçaria ou de espiritismo. Esses crimes constavam do Código Penal de 1890, que vigorava na época e servia de amparo legal para as perseguições aos terreiros. $\mathrm{Na}$ então capital federal, Rio de Janeiro, estava em vigor desde 1934 uma lei que colocava os grupos praticantes do kardecismo e das religiões afro-brasileiras fosse a macumba ou a nascente umbanda - e os maçons sob jurisdição do Departamento de Tóxicos e Mistificações da polícia, na seção especial de Costumes e Diversões, que lidava com questões relacionadas a drogas, jogo ilegal e prostituição (BROWN, 1985, p. 13). Esses grupos necessitavam de uma autorização policial para exercerem suas práticas7.

A partir dos anos 1930, a umbanda começa, assim, a buscar caminhos para se institucionalizar e se legitimar como religião. A repressão policial, na interpretação de Diana Brown (1985), estimulou os umbandistas a se organizarem, visando sua própria proteção. Assim, em 1939, foi criada no Rio de Janeiro a União Espírita da Umbanda do Brasil (UEUB), a primeira de dezenas de entidades representativas dos umbandistas que surgem no decorrer do século XX. A UEUB

\footnotetext{
${ }^{7}$ A exigência do registro dos terreiros em instâncias policiais é uma determinação de governos estaduais, que é observada em outros momentos e em estados diferentes. A Lei 3.097, de 1972, do estado da Bahia (BAHIA, 1972), obrigou o registro em delegacia de polícia até 1976; e a Lei 3.443, de 1966, do estado da Paraíba (PARAíBA, 1966), subordinava o funcionamento dos terreiros à autorização concedida pela Secretaria de Segurança Pública, além da apresentação de prova de sanidade mental do responsável pela casa, mediante realização de exame psiquiátrico (SILVA JÚNIOR, 2007, p. 310).
} 
foi organizada pelos próprios praticantes da umbanda, que tentavam desassociar a herança africana da imagem da religião que estavam buscando institucionalizar (BROWN, 1985; BIRMAN, 1985; ORTIZ, 1978). Como observa Patrícia Birman (1985), ao estudar as federações umbandistas do Rio de Janeiro:

\begin{abstract}
Se para uma corrente expressiva da intelectualidade dominante, os cultos afro dignos de respeito eram aqueles que se conservavam "puros" e alheios à influência da cultura branca, para os intelectuais que formavam a primeira federação umbandista exatamente o oposto era valorizado. Quanto mais se "embranquecessem" os cultos, mais legítima se tornaria a religião. (BIRMAN, 1985, p. 87).
\end{abstract}

Esse posicionamento refletiu nas discussões do primeiro Congresso de Espiritismo de Umbanda, ocorrido em 1941, também no Rio de Janeiro. Nas atas do congresso, seus participantes externaram a preocupação de criar uma umbanda desafricanizada e o esforço para "branquear" ou "purificar" a umbanda, dissociando-a da África, entendida como "primitiva" e "bárbara". Havia também uma ênfase na caridade, sendo uma missão da umbanda "resgatar as classes subalternas das formas exploradoras e nocivas de feitiçaria" (BROWN, 1985, p. 1112). Aqui, uma clara referência ao espiritismo kardecista, que se apoiou na ideia de caridade para se legitimar no espaço público, entre o fim do século XIX e as primeiras décadas do século XX. (GIUMBELLI, 2008).

Ao mesmo tempo, essa vertente umbandista adotava em suas práticas outros elementos que remetiam à África, mas com uma outra roupagem em uma tentativa de se afastar do estigma do feitiço. Em seu panteão, por exemplo, constava o pretovelho: uma representação do africano escravizado, valorizado por sua benevolência e sábios conselhos, características que o distanciavam da ideia de feitiçaria então associada às práticas religiosas dos negros. Além dos elementos que remetiam à África, a umbanda que surgia no Rio de Janeiro, centrada na UEUB, recorria também a elementos indígenas e católicos para se autodefinir como brasileira, tendo como base doutrinária o espiritismo kardecista, difundido no Brasil ainda no século XIX. 
A partir dos textos que compõem os anais do referido congresso umbandista, Emerson Giumbelli (2010) chama atenção para o fato de que, apesar de uma recusa da África, o continente se fazia presente não somente nas práticas rituais como nas narrativas sobre a genealogia da religião. Essas narrativas eram elaboradas por aqueles que estavam envolvidos com a institucionalização da umbanda entre as décadas de 1930 e 1940, no Rio de Janeiro. Tais textos apresentam versões sobre a origem da umbanda que remetem à África e apontam também as pretensões da nascente religião: atuar no presente combatendo o mal e contribuir para o surgimento de uma nação mais evoluída. Para Giumbelli, a umbanda articulada por esses pioneiros reconhecia, assim, o papel da África para a construção de uma modernidade nacional, "para a qual não eram suficientes as forças e as personagens de uma civilização de inspiração europeia ou ocidental” (GIUMBELLI, 2010, p. 115). Vale lembrar o que Renato Ortiz (1978) chama de movimento de "empretecimento": quando a umbanda absorve as crenças tradicionais afro-brasileiras sem valorizar efetivamente as tradições negras. O reconhecimento da África como apontado por Giumbelli seguiria, a meu ver, o entendimento de Ortiz para o movimento de "empretecimento".

Roger Bastide (1995) já havia indicado, nos seus estudos publicados em 1960, a recusa e a adoção pela umbanda de elementos que remetiam a uma herança africana. Essa aparente contradição era externada nas representações mitológicas e etimológicas que tratavam da origem da umbanda e que foram apresentadas no congresso de 1941. Tal contradição, para Bastide, apontava para a relação entre brancos e negros na sociedade brasileira, uma relação em que o preconceito racial se fazia presente. Assim, para o autor, o sagrado era o lugar do encontro dos interesses humanos, das atitudes de classe, apresentando-se como um reflexo das estruturas urbanas (BASTIDE, 1995, p. 447). No momento em que a umbanda buscava legitimar-se, a negação de sua herança africana era uma estratégia contra a repressão dos aparelhos judiciário e policial do Estado, como lembra Lísias Nogueira Negrão (1996). 
Buscando entender como se efetuava a integração e a legitimação da umbanda na sociedade brasileira, Ortiz comparou-a ao candomblé, seguindo os passos de seu orientador Roger Bastide. Primeiramente, ele apontava que "a Umbanda corresponde à integração das práticas afro-brasileiras na 'moderna' sociedade brasileira; o candomblé significa justamente o contrário, isto é, a conservação da memória coletiva africana no solo brasileiro" (ORTIZ, 1978, p. 13). E, na sequência, afirmava: "para o candomblé a África conota a ideia de terra Mãe, significado de retorno nostálgico a um passado negro. Sob este ponto de vista a Umbanda difere radicalmente dos cultos afro-brasileiros, ela tem consciência de sua brasilidade, ela se quer brasileira" (ORTIZ, 1978, p. 14).

\section{Genuinamente brasileira}

A ideia da umbanda como uma religião brasileira foi gestada pelo grupo envolvido com sua institucionalização no Rio de Janeiro dos anos 1920 e 1930. Grupo que estava atento a outros movimentos promovidos no Brasil, no mesmo período, em torno de uma concepção de nação brasileira. As observações sobre a tendência de a umbanda ora buscar um "embranquecimento", como cunhou Bastide, ora um "empretecimento", segundo Ortiz, são recorrentes nos estudos que abordam o surgimento da religião. Na mesma década de 1970 em que Ortiz realizava a sua pesquisa, Maria Helena Vilas Bôas Concone (1987) também estava em campo, desenvolvendo um trabalho em que refletia sobre a formulação da umbanda como uma religião brasileira. Ela destacou não apenas dois, mas três movimentos. Os dois primeiros se assemelham às considerações de Bastide e Ortiz, sendo o "branqueamento" um movimento para depurar as características tidas como primitivas da umbanda, que buscará se vincular ao cristianismo, ao kardecismo e até ao orientalismo. O movimento de "negritude" afirma uma origem africana para a umbanda, considerando-a a mais antiga religião do mundo. Um terceiro movimento é o de valorização do elemento indígena. São esses três movimentos reunidos que sustentam a definição da umbanda como uma religião brasileira, tal como propõe a autora. 
Em um trabalho posterior, Maria Helena Vilas Bôas Concone (1981) sugeriu que a afirmação da umbanda como uma religião genuinamente brasileira quando de sua conformação, nos anos 1920 e 1930, estava relacionada ao pensamento nacionalista, que se expressava na arte e na literatura - com destaque para os modernistas da Semana da Arte Moderna de São Paulo, de 1922 - e também em movimentos político-ideológicos, como o integralismo - movimento autoritário inspirado no fascismo italiano, que inicialmente teve o apoio de Getúlio Vargas. Naquele momento, ganhava destaque a ideia de nação brasileira formada a partir da mistura das três "raças": o branco, o negro e o indígena. A partir dos escritos de autores como Gilberto Freyre, Donald Pierson e Arthur Ramos , foi forjada a ideia de que o Brasil mestiço seria a solução em um mundo marcado por divisões de classe, origem e cor. Uma concepção incorporada pelo governo de Getúlio Vargas na tentativa de empreender uma representação da nação brasileira (SCHWARCZ, 2012).

Como observa Maria Isaura Pereira de Queiroz (1989), na década de 1920 dois estratos sociais têm a heterogeneidade do patrimônio cultural brasileiro como importante valor para significar a identidade nacional: o grupo de jovens intelectuais burgueses, de formação universitária, que a definem no âmbito de uma teoria explicativa, e os grupos que fazem dela o núcleo central da nova religião, a umbanda. A autora afirma que os primeiros proclamavam explicitamente, em seus textos e trabalhos, a relevância da heterogeneidade cultural brasileira, enquanto os outros a admitiam implicitamente, por meio dos princípios de sua fé religiosa. Para ela, tal convergência não era gratuita, podendo ser resultado das circunstâncias sócio-históricas em que as novas teorias da identidade cultural nacional - a filosófica e a religiosa - surgiram.

A umbanda que se difundia no Sudeste brasileiro no primeiro quartel do século XX buscava: enaltecer uma herança africana ou desqualificá-la; valorizar as aproximações com o kardecismo, espelhando-se em sua estrutura burocrática para fundar suas associações e fazendo da umbanda também uma religião de caridade; associar elementos do catolicismo a seus rituais; creditar ao indígena uma posição 
de destaque em seu panteão. Assim, a nascente religião se constituía de elementos representativos das ditas três raças que, misturadas, compunham uma ideia de Brasil cunhada por intelectuais dos anos 1920, pensando nos modernistas, e dos anos 1930, a geração que se volta para a discussão da questão racial no país. A umbanda se definia em contraste com a magia e o curandeirismo, associando-se à ideia de caridade e evolução espiritual presentes no kardecismo e destacando o seu caráter nacional.

Eram diversos, e mesmo contraditórios, os argumentos usados com vistas a legitimar a umbanda. A pluralidade dos argumentos derivava da presença de mais de uma vertente umbandista na busca pela institucionalização da religião. Os esforços dos umbandistas que estiveram à frente da organização do congresso de 1941 se voltavam para a unificação dessas vertentes, empenhando-se em fazer da umbanda a "união de todas as bandas" - para empregar aqui uma expressão da época, ainda corrente nos templos.

\section{Tata de Umbanda}

O Brasil, que havia iniciado nos anos 1930 a travessia do rural para o urbano, chegava ao final da década de 1950 engrenado no desenvolvimentismo, que já mudava a paisagem das cidades, principalmente as do Sudeste, que cresciam de forma desordenada. A prática das religiões afro-brasileiras ainda era cerceada. Mesmo assim, crescia a umbanda que buscava se embranquecer associando-se à doutrina kardecista e, também, outra vertente que enaltecia uma herança africana. A religião tida como genuinamente brasileira ressaltava com o sacerdote Tancredo da Silva Pinto seu lado afro. Ele nasceu no Rio de Janeiro, no início do século XX. Era conhecido entre os sambistas da época, tendo inclusive composto alguns sambas, e bem articulado com o meio político. Fundou a Federação Espírita Umbandista, em 1952, no Rio de Janeiro e, a partir dela, outras federações em alguns estados brasileiros. Apesar de sua atuação preponderante entre as décadas de 1950 e 1970 na divulgação das religiões afro-brasileiras, ele recebeu pouco destaque nos estudos sociológicos e antropológicos sobre tais religiões. 
Tancredo viajava pelo país divulgando seus conhecimentos, que também eram transmitidos em livros, como no Minas sob a luz da umbanda, assinado com um de seus filhos de santo, Antônio Pereira Camêlo. Nesse livro, salientava-se a herança africana: "Com a religião dos prêtos (sic) as Nações Africanas tais como Nagô, Angola, Congo, Moçambique, etc., formou-se a Umbanda que quer dizer unificação das bandas" (PINTO; CAMÊLO, 1971, p. 19). Desta forma, a umbanda era a união das bandas, ou seja, das nações africanas.

O termo nações, no trecho citado acima, não se refere aos estados nacionais, lembrando aqui a teoria de Benedict Anderson (2008), apesar de três das "nações africanas" listadas coincidirem com as denominações adotadas na atualidade por países, como Angola, Congo e Moçambique. Esse termo remete, conforme sugere J. Lorand Matory (1999), aos grupos étnicos africanos constituídos na diáspora sob o poder dos colonizadores. "De fato, essas nações eram freqüentemente (sic) agrupamentos impostos a diversos povos e a distintas ordens de categorias políticas, linguísticas e culturais que foram unificados primariamente para os propósitos dos traficantes de escravos" (MATORY, 1999, p. 58). Como aponta Luis Nicolau Parés (2007, p. 24-25), os nomes das nações não eram homogêneos e remetiam a portos de embarque, reinos, etnias, ilhas ou cidades. Traficantes e senhores de escravos usavam tais nomes no intuito de atender aos seus interesses de classificação administrativa e controle, sendo que, em muitos casos, os portos ou região geográfica de embarque dos africanos teriam sido um dos principais critérios de construção dessas categorias, ou seja, as nações.

As nações impostas a cada grupo passaram a distinguir também as religiões praticadas por seus integrantes. Assim, no entendimento de Roger Bastide (2001), "na Bahia não existem mais hoje indivíduos eves, iorubás, angolas ou congos, mas essas 'nações', todavia, sobreviveram sob forma de candomblé, ritual ou musicalmente diferentes" (BASTIDE, 2001, p. 261). Em Bastide estava presente a ideia de uma permanência, de uma manutenção do modo de vida africano transposto para a religião praticada pelos negros baianos, sobretudo o candomblé nagô. Vivaldo da Costa Lima (1976) também relaciona as nações africanas às do candomblé, porém evidenciando uma mudança entre as duas concepções: 
A nação, portanto, dos antigos africanos na Bahia foi aos poucos perdendo sua conotação política para se transformar num conceito quase exclusivamente teológico. Nação passou a ser, desse modo, o padrão ideológico e ritual dos terreiros de candomblé da Bahia estes sim, fundados por africanos angolas, congos, jejes, nagôs, - sacerdotes iniciados de seus antigos cultos, que souberam dar aos grupos que formaram a norma dos ritos e o corpo doutrinário que se vêm transmitindo através os tempos e a mudança nos tempos. (LIMA, 1976, p. 77).

Assim, estudiosos e também adeptos passaram a adotar uma classificação que distingue os grupos que praticam o candomblé a partir de nações. Há o candomblé de "nação" angola, jeje, keto, efon, dentre outras. Ressalta-se que são termos que diferem dos listados no trecho destacado aqui do livro de Tancredo da Silva Pinto e de seu filho de santo Antônio Camêlo. Há uma outra diferença. Se no candomblé as "nações" são uma forma de distinção, na umbanda da vertente de Tancredo da Silva Pinto - que ficou conhecido como Tata de Umbanda, sendo Tata um título sacerdotal também adotado no candomblé angola -, as “nações" eram agrupadas para dar corpo mítico-ritual à religião.

Dentre as "nações”, no entanto, uma destacava-se na formação de um novo culto difundido por ele. A "nação" era angola e o culto, omolocô, que não constava na geografia descrita por Bastide. O omolocô, por vezes, é caracterizado como uma umbanda mais africanizada por ter iniciação, como no candomblé; por incluir em seu panteão divindades africanas; e por vincular sua origem ao povo lunda-quioco, proveniente da região onde atualmente está localizado o país Angola, na África ${ }^{8}$. Mas, para Tancredo da Silva Pinto não havia uma umbanda mais ou menos africanizada, já que em seu entendimento a umbanda era uma religião cuja matriz era a África, diferentemente da vertente umbandista que a definiu como brasileira9. Em um de seus livros, As Mirongas de Umbanda (1957) - em coautoria com outro filho de santo seu, Byron Torres de Freitas - reforçava-se o laço com a África:

\footnotetext{
${ }^{8}$ Ressalta-se aqui somente o fato de tanto o omolocô quanto o candomblé terem rituais de iniciação religiosa. No entanto, tratam-se de rituais distintos.

${ }^{9}$ De acordo com os anais do Primeiro Congresso Brasileiro do Espiritismo de Umbanda (PRIMEIRO..., 1942), realizado em 1941, con stam discursos que acionam uma origem africana para a umbanda. No entanto, tal origem não estava vinculada às nações apresentadas por Tancredo. Há uma versão para a origem da umbanda que a vincula, por exemplo, ao Egito.
} 
A Umbanda, como tôdas (sic) as demais religiões, compreende duas partes: o ensino secreto, reservado aos iniciados, e o culto externo, público. Não há Umbanda negra nem Umbanda branca. Umbanda quer dizer linha de chão e compreende hoje os cultos Nagô, Gêge, Omolocô (ou Angola), Malê, Congo, Cabinda, Benguela, Caçange, Costa d'África. (PINTO; FREITAS, 1957, p. 79).

A partir do trecho acima, entende-se o omolocô como um dos cultos que compõem a umbanda, podendo ainda ser denominado angola. Nos escritos de Tancredo da Silva Pinto mencionados nesta seção, ora o omolocô era tomado como parte de uma religião, no caso a umbanda, ora configurava ele próprio uma religião. O interesse aqui não é de definir o que era o omolocô para Tancredo da Silva Pinto, mas salientar a forma como esse sacerdote buscou legitimar a umbanda: afirmando-a como religião, uma religião formada a partir de matrizes africanas.

Para além da ênfase em uma origem africana da umbanda, os meios acionados por Tancredo da Silva Pinto para divulgar seu posicionamento merecem relevo. Dois deles já foram citados. O primeiro é a criação de entidades civis representativas dos umbandistas, visando estabelecer uma organização hierárquica e garantindo proteção aos terreiros (PINTO; FREITAS, 1957). Conforme mencionado, ele participou não apenas da organização da Federação Espírita Umbandista no Rio de Janeiro, como de outras entidades pelo Brasil ${ }^{10}$. A criação dessas entidades segue o caminho escolhido pelo grupo de pioneiros da umbanda e que, por sua vez, adotava a orientação dos kardecistas no processo de institucionalização de sua religião no Brasil. O outro meio citado foi a produção de uma literatura especializada. Tancredo da Silva Pinto publicou mais de uma dezena de livros sobre a umbanda, sendo alguns em coautoria, em que abordava os rituais e a história da religião e buscava decodificar a umbanda. Esse já era um meio explorado não somente pelo grupo de pioneiros da umbanda, como também pelos kardecistas.

\footnotetext{
${ }^{10}$ Tancredo da Silva Pinto se desvincula da Federação Espírita Umbandista pouco tempo depois de sua criação e contribui para a fundação da Confederação Espírita Umbandista. Há uma dificuldade em se precisar as datas de fundação dessas entidades, uma vez que nem sempre são coincidentes as datas apontadas pelas fontes secundárias consultadas na pesquisa que foi base para este trabalho.
} 
Os periódicos - fossem os da imprensa diária ou os vinculados às associações umbandistas - também eram meios de divulgação para Tancredo da Silva Pinto. Diana Brown (1985), que ficou admirada com a popularidade do sacerdote nos terreiros das favelas do Rio de Janeiro quando de sua pesquisa em 1966, registrou uma coluna assinada por Tancredo da Silva Pinto no jornal O Dia, que tinha grande circulação à época na cidade. Mais uma vez, ressalta-se o uso de uma estratégia também adotada pelos pioneiros da umbanda, que no âmbito da União Espírita da Umbanda no Brasil (UEUB) já tinham criado, por exemplo, o Jornal de Umbanda, em 1949.

A organização de festas religiosas em locais públicos soma-se às formas de divulgação da umbanda por Tancredo da Silva Pinto. Em Minas Gerais, por exemplo, ele participou da fundação da Federação Espírita Umbandista do Estado de Minas Gerais, em 1956. A partir de 1957, essa federação passou a organizar a Festa de Iemanjá, que ocorre na Lagoa da Pampulha, na capital Belo Horizonte. Como o estado não é banhado pelo mar, Iemanjá, a rainha das águas, era evocada como Ialoxá, a deusa dos lagos. A presença de Tancredo da Silva Pinto era constante nos eventos da federação mineira e ele acabou iniciando muitos filhos de santo no estado, onde ainda hoje, mais de 30 anos depois do seu falecimento, é considerado uma referência em se tratando de religiões afro-brasileiras, de forma específica o omolocô (MORAIS, 2010).

\section{Coalizão de forças}

Se com Tancredo da Silva Pinto o lado afro da umbanda era enaltecido, a divulgação de seus posicionamentos era feita em meios já adotados pela vertente umbandista que tentava se afastar da herança africana, tal como propuseram os pioneiros do movimento federativo que criaram a União Espírita da Umbanda no Brasil (UEUB) em 1939. Nos anos 1950, outras entidades buscavam representar os umbandistas, haja vista as federações que contaram com a participação de Tancredo da Silva Pinto em sua fundação, como mencionado aqui. Além da 
umbanda que buscava na África suas raízes, a vertente que se associava aos ditames kardecistas e também aos cristãos - nomeada umbanda branca ou umbanda pura, marcando o corte racial - fundava suas federações (BROWN, 1985; NEGRÃO, 1996) ${ }^{11}$.

Essas duas vertentes podem se apresentar como extremos do movimento federativo, que, no entanto, constituiu-se a partir de diferentes matizes umbandistas. Como aponta Lísias Negrão (1996), ao abordar a formação do campo umbandista em São Paulo:

A identidade da Umbanda não se afirma, pois, de forma unívoca, mas duplamente dividida: de um lado, entre as necessidades de sua afirmação enquanto culto específico e as pressões homogeneizadoras das demandas por legitimação; de outro, entre os apelos diferenciadores do cultivo às raízes e a adesão integradora à ideologia nacionalista. Não se trata de identidade definida, mas em processo de construção, em que elementos culturais de diversas origens sincretizam-se e, em função das necessidades do momento, derivadas das trocas com a sociedade global, prevalecem ou são deixadas na obscuridade. (NEGRÃO, 1996, p. 170).

Dessa forma, as duas vertentes poderiam opor-se ou mesmo atuar em conjunto, evidenciando a dinâmica do movimento federativo. Conforme relata Diana Brown (1985), em meados dos anos 1950, no Rio de Janeiro, havia um tratamento hostil entre os representantes das duas vertentes, que tinham suas diferenças marcadas social e racialmente. Porém, em 1956, esses representantes propuseram uma coalizão e conseguiram agrupar cinco federações tidas como mais ativas no Rio de Janeiro para fundar o Colegiado Espírita do Cruzeiro do Sul. Tancredo da Silva Pinto era um dos presidentes da entidade ${ }^{12}$.

\footnotetext{
${ }^{11}$ É interessante notar o uso do termo umbanda pura. No caso da umbanda, a pureza estava relacionada à recusa dos elementos africanos. No candomblé, a pureza está associada justamente à adoção dos elementos africanos. É considerado mais puro o cando mblé que se mantém fiel às heranças africanas.

${ }^{12}$ Outras iniciativas de coalizão entre as federações são registradas na segunda metade do século XX, conforme apontado por Patrícia Birman (1985). Normalmente, tais coalizões têm curta duração, o que é comum também entre as federações. Nos dois casos há um problema de legitimação da entidade perante seus filiados, uma vez que na umbanda, assim como no candomblé, os terreiros têm sua autonomia, tornando incompatível a subordinação a uma outra instância, no caso a federação. Para estudos sobre as federações umbandistas, ver Birman (1985), Brown (1985) e Negrão (1996).
} 
Juntas, essas federações buscavam ampliar seu reconhecimento público, entrando para a política partidária, com vistas a eleger umbandistas para mandatos legislativos. Nas eleições de 1958, foi eleito o primeiro vereador umbandista do Rio, Átila Nunes. Em outros estados brasileiros, as federações também se organizavam nesse sentido. No mesmo 1958, o umbandista Moab Caldas se elegeu deputado estadual no Rio Grande do Sul. A defesa da prática da umbanda passava assim a constar na pauta do debate legislativo, sob a temática da liberdade religiosa. Tanto Átila Nunes quanto Moab Caldas ficaram conhecidos entre os umbandistas por meio de programas de rádio, um outro meio de divulgação da religião que ganhava novos fiéis e, por isso, incomodava uma antiga detratora das religiões afrobrasileiras: a igreja católica.

Nesse mesmo período, a umbanda passou a ser alvo de uma forte campanha da igreja católica, como registram Diana Brown (1985) e Lísias Negrão (1996). Os católicos que frequentassem terreiros de umbanda eram condenados e ameaçados de excomunhão. Frei Boaventura Klopppenburg foi designado por dom Helder Câmara, já no âmbito da então recém-criada Confederação Nacional dos Bispos do Brasil (CNBB), a realizar uma pesquisa nos terreiros. Essa pesquisa foi publicada no livro Umbanda no Brasil: orientação para católicos, em 1961, que, em particular, atacava a umbanda e, em geral, o espiritismo (KLOPPENBURG, 1961). Esse posicionamento da igreja católica começou a mudar em 1962 com o Concílio Vaticano II, o que resultou em uma maior tolerância às influências culturais negras em rituais populares.

Também em 1961 foram realizados dois encontros de umbandistas, o I Congresso Paulista de Umbanda, em Santos (SP), e o II Congresso do Espiritismo de Umbanda, no Rio de Janeiro (RJ), 20 anos após o I Congresso. Essa segunda edição do encontro ocorreu no Maracanãzinho, atraindo umbandistas de dez estados brasileiros e representantes do poder público estadual e municipal. Era a umbanda que mostrava o seu crescimento. Ainda não havia uma contagem oficial dos brasileiros que se declaravam umbandistas. Tal crescimento era atestado pela 
popularidade que a religião adquiria, divulgada nos meios de comunicação; pelos participantes de eventos religiosos em locais públicos; e pelo registro de novos terreiros ${ }^{13}$.

Somente no Censo de 1964 é que a umbanda foi incluída no questionário do Instituto Brasileiro de Geografia e Estatística (IBGE). Estava, assim, reconhecida oficialmente como religião. Tal reconhecimento se deu em plena ditadura militar, indicando uma aproximação entre militares e umbandistas que integravam o movimento federativo. Frisa-se aqui que se tratava de um grupo que praticava a religião e estava envolvido com articulações políticas, e não da totalidade dos umbandistas, uma vez que muitos nem mesmo se vinculavam às federações. Fato é que a inclusão da umbanda na relação das religiões consideradas no Censo demonstrava não apenas o crescimento do número de adeptos, mas, sobretudo, a constituição dos umbandistas como um grupo de interesse político, visando votos nas eleições (BROWN, 1985; NEGRÃO, 1996).

\section{Conclusão}

Da perseguição ao reconhecimento do Estado: uma trajetória percorrida pela umbanda entre seu surgimento, no início do século XX, à década de 1960. Tal reconhecimento não deslocou a umbanda de uma situação marginal, tampouco representou o fim das perseguições aos seus praticantes. Mas contribuiu para a sua afirmação como religião, reivindicada desde os umbandistas pioneiros, criadores da primeira federação, em 1939. A religião mirada por eles e defendida por umbandistas que lhes sucederam e encorparam o movimento federativo tinha como "modelo ideal" - termo adotado por Lísias Negrão (1996) - o catolicismo, de onde procuraram absorver a racionalidade institucional e a moralidade cristã. E, como "modelo real" o kardecismo, filtrando pela ótica espírita a organização política em federações, somada ao emprego da noção de caridade (NEGRÃO, 1996,

\footnotetext{
${ }^{13}$ Em São Paulo, Lísias Negrão (1996) aponta para um crescimento no número de terreiros de umbanda registrados em cartório, que parte de 42, entre os anos de 1929 a 1944, atingindo a marca de 2.844, seu ápice, entre os anos de 1974 e 1976 . O período analisado por Negrão vai de 1929 a 1989.
} 
p. 86-87). Ou seja, eram duas as fontes que baseavam a ideia de religião construída pelos umbandistas que atuaram no intuito de legitimar a umbanda.

O processo de legitimação da umbanda foi iniciado com um movimento que buscava "embranquecer" a religião, mas somente foi alcançado com o apoio daqueles que afirmavam a sua herança africana. Conforme destaca Diana Brown:

Esses ganhos políticos, e a crescente legitimidade que eles trouxeram para a Umbanda, estavam diretamente relacionados com o maior apoio eleitoral do setor inferior que os políticos umbandistas obtiveram através de alianças com terreiros afro-brasileiros daquele setor. É altamente discutível afirmar que esses ganhos teriam ocorrido sem este apoio. Essas alianças levaram à formação de uma religião claramente pluriclassista, e reuniram dois setores sociais distintos que praticavam formas de Umbanda extremamente contrastantes. Nesse sentido, elas provocaram um grau maior de tolerância mútua da Umbanda enquanto religião heterodoxa. (BROWN, 1985, p. 27-28).

A aproximação das duas vertentes da umbanda que pareciam antagônicas, observada no Rio de Janeiro por Diana Brown, aconteceu entre as décadas de 1950 e 1960, a partir das articulações do movimento federativo, visando interesses políticos. Era o lado afro da umbanda que passava a ser aceito e afirmado tal qual já propagava Tancredo da Silva Pinto. No entanto, a umbanda ainda oscila entre a afirmação e a negação de seu lado afro, como fica explícito no processo de criação do Dia Nacional da Umbanda, com o qual finalizo este artigo.

Desde 16 de maio de 2012, está presente no calendário oficial brasileiro o Dia Nacional da Umbanda. A data - instituída pela presidenta Dilma Rousseff por meio da Lei 12.644 (BRASIL, 2012) e referendada pelas então ministras Ana de Hollanda, da Cultura, e Luiza Bairros, da Secretaria de Políticas de Promoção da Igualdade Racial (SEPPIR) - passou a ser comemorada em 15 de novembro. Nesse dia, no ano de 1908, conforme um dos mitos fundadores da umbanda, o médium Zélio de Moraes recebeu, em Niterói (RJ), do Caboclo das Sete Encruzilhadas, a missão de fundar a religião. Ressalta-se: em 15 de novembro, já se celebra, com direito a feriado nacional, a proclamação da República. 
Foi ao pluralismo religioso, bem como ao direito constitucional da liberdade de crença, que o então deputado federal Carlos Santana, autor do projeto que originou a lei, recorreu, em 2005, ao justificar a relevância da matéria: "Pretendemos com essa iniciativa confirmar o livre exercício dos cultos religiosos e permitir que se conheça e se propague a Umbanda como uma das manifestações religiosas presentes em nosso país" (BRASIL, 2012). No mesmo documento, o deputado informa que a umbanda é "uma religião eminentemente brasileira, embora com raízes africanas". Destaca-se na frase anterior a conjunção "embora", que pode ser interpretada como uma contradição a uma possível expectativa. No caso, seria contraditório a umbanda ser "eminentemente brasileira" e ter "raízes africanas”.

Como demonstrado aqui, ao longo do século XX, a umbanda foi ora vinculada, ora desvinculada de suas heranças africanas. $\mathrm{O}$ mesmo ocorre em alguns procedimentos relacionados à proposição da lei que institui o Dia Nacional da Umbanda. Na justificativa do projeto, a ênfase é para o caráter brasileiro da religião. E na publicação do Diário Oficial da União consta, juntamente com a assinatura da presidenta Dilma Rousseff, a assinatura da ministra Luiza Bairros, que estava à frente da Seppir e tinha uma trajetória de militância no movimento negro. A institucionalização da data foi noticiada no site da Seppir acompanhada da seguinte explicação sobre a origem da umbanda: "[...] é uma religião genuinamente brasileira, mas com raízes, entre outras, africanas, que se constituiu no início do século passado" (BRASIL, 2012). Mais uma vez a umbanda é destacada como uma religião brasileira. No entanto, diferentemente da justificativa do projeto de lei, na notícia veiculada no site da Seppir a conjunção "mas" está reforçando o fato de a umbanda ter "raízes africanas". 


\section{REFERÊNCIAS}

ANDERSON, Benedict. Comunidades imaginadas: reflexões sobre a origem e a difusão do nacionalismo. São Paulo: Companhia das Letras, 2008.

ANDRADE, Mário de. Geografia religiosa do Brasil. Publicações Médicas, ano 13, n. 124, p. 71-84, ago. 1941.

ANDRADE, Mário de. Música de feitiçaria no Brasil. 2. ed. Belo Horizonte: Itatiaia, 1983.

BAHIA. Lei no 3.097, de 26 de dezembro de 1972. Dispõe sobre taxas pelo exercício do poder de polícia e pela prestação de serviços, e dá outras providências. Diário Oficial do Estado, Salvador, 29 dez. 1972.

BASTIDE, Roger. Les religions africaines au Brésil. Paris: PUF, 1995.

BASTIDE, Roger. O candomblé da Bahia: rito nagô. São Paulo: Companhia das Letras, 2001.

BIRMAN, Patrícia. Registrado em cartório, com firma reconhecida: a mediação política das federações de umbanda. In: BROWN, Diana et al. Umbanda e política. Rio de Janeiro: ISER: Marco Zero, 1985. p. 80-121. (Cadernos do ISER, 18).

BRASIL. Ministério dos Direitos Humanos. Presidenta institui Dia da Umbanda. Secretaria de Políticas de Promoção da Igualdade Racial. Brasília: SEPPIR, 18 maio 2012. Disponível em: http://www.seppir.gov.br/portalantigo/noticias/ultimas_noticias/2012/o5/presidenta-institui-dia-da-umbanda. Acesso em: 15 jun. 2017.

BROWN, Diana. Uma história da umbanda no Rio. In: BROWN, Diana et al. Umbanda e política. Rio de Janeiro: ISER: Marco Zero, 1985. p. 9-42. (Cadernos do ISER, 18).

CAMARGO, Cândido Procópio Ferreira de. Kardecismo e umbanda: uma interpretação sociológica. São Paulo: Livraria Pioneira Editora, 1961.

CONCONE, Maria Helena Villas Bôas. Ideologia umbandista e integralismo. In:

ALMEIDA, Maria Herminia Tavares de et al. Trabalho e cultura no Brasil. Recife:

ANPOCS; Brasília: CNPq, 1981. (Ciências Sociais Hoje, 1).

CONCONE, Maria Helena Villas Bôas. Umbanda, uma religião brasileira. São Paulo: FFLCH/USP-CER, 1987.

GIUMBELLI, Emerson. A presença do religioso no espaço público: modalidades no Brasil. Religião \& Sociedade, Rio de Janeiro, v. 28, n. 2, p. 80-101, 2008.

GIUMBELLI, Emerson. Presença na recusa: a África dos pioneiros umbandistas. Esboços, Florianópolis, v. 17, n. 23, p. 107-118, 2010.

GIUMBELLI, Emerson. Zélio de Moraes e as origens da umbanda no Rio de Janeiro. In:

SILVA, Vagner Gonçalves da (org.). Caminhos da alma. São Paulo: Selo Negro, 2002. p. $183-217$. 
KLOPPENBURG, Boaventura. A umbanda no Brasil: orientação para os católicos. Petrópolis: Vozes, 1961.

LIMA, Vivaldo da Costa. O conceito de "nação" nos candomblés da Bahia. Afro-Ásia, Salvador, n. 12, p. 65-90, 1976.

MATORY, J. Lorand. Jeje: repensando nações e transnacionalismo. Mana, Rio de Janeiro, v. 5 , n. 1, p. 57-80, abr. 1999.

MORAIS, Mariana Ramos de. De religião a cultura, de cultura a religião: travessias afro-religiosas no espaço público. Belo Horizonte: Editora PUC Minas, 2018.

MORAIS, Mariana Ramos de. Nas teias do sagrado: registros da religiosidade afrobrasileira em Belo Horizonte. Belo Horizonte: Editora Espaço Ampliar, 2010.

NEGRÃO, Lísias Nogueira. Entre a cruz e a encruzilhada: formação do campo umbandista em São Paulo. São Paulo: Edusp, 1996.

ORTIZ, Renato. A morte branca do feiticeiro negro: Umbanda, integração de uma religião numa sociedade de classes. Petrópolis: Vozes, 1978.

PARAÍBA. Lei $\mathrm{n}^{\circ}$ 3.443, de 06 de novembro de 1966. Dispõe sobre o exercício dos cultos africanos no estado da Paraíba. Diário Oficial do Estado, João Pessoa, 10 nov. 1966.

PARÉS, Luis Nicolau. A formação do candomblé: história e ritual na nação jeje na Bahia. Campinas: Editora da Unicamp, 2007.

PINTO, Tancredo da Silva; CAMÊLO, Antônio Pereira. Minas sob a luz da umbanda. Belo Horizonte: Editora G. Holman, 1971.

PINTO, Tancredo da Silva; FREITAS, Byron Torres de. As mirongas de umbanda. 3 . ed. Rio de Janeiro: Gráfica Editora Aurora, 1957. (Coleção Espiritualista, 4).

PRIMEIRO congresso brasileiro do espiritismo de umbanda. Trabalhos apresentados ao $1^{\circ}$ Congresso Brasileiro do Espiritismo de Umbanda, reunido no Rio de Janeiro, de 19 a 26 de Outubro de 1941. Rio de Janeiro: Federação Espírita de Umbanda, 1942.

QUEIROZ, Maria Isaura Pereira de. Identidade cultural, identidade nacional no Brasil. Tempo Social, São Paulo, v. 1, n. 1, p. 29-46, 1989.

RAMOS, Arthur. O negro brasileiro. Rio de Janeiro: Graphia, 2001.

SCHWARCZ, Lilia Moritz. Do preto, do branco e do amarelo: sobre o mito nacional de um Brasil (bem) mestiçado. Ciência e Cultura, São Paulo, v. 64, n. 1, p. 48-55, jan. 2012.

SILVA JÚNIOR, Hédio. Notas sobre sistema jurídico e intolerância religiosa no Brasil. In: SILVA, Vagner Gonçalves da (org.). Intolerância religiosa: impactos do neopentecostalismo no campo religioso afro-brasileiro. São Paulo: Edusp, 2007. p. 303323 . 